\title{
PENGUKURAN KUALITAS HIDUP SEBAGAI INDIKATOR STATUS KESEHATAN KOMPREHENSIF PADA INDIVIDU LANJUT USIA
}

\author{
Marcella Erwina Rumawas
}

Fakultas Kedokteran, Universitas Tarumanagara Jakarta

Email: marcellar@fk.untar.ac.id

\begin{abstract}
ABSTRAK
Indonesia mengalami transisi demografis menuju struktur penduduk tua yang tidak hanya berdampak pada bidang kesehatan, namun juga pada berbagai aspek kehidupan. Kompleksitas proses penuaan dan kerentanan lansia menderita beberapa penyakit kronik, menyebabkan konsep "sakit vs sembuh" maupun indikator angka kesakitan sulit mencerminkan status kesehatan dan keberhasilan program kesehatan lansia. Walaupun digunakan untuk mengevaluasi keberhasilan terapi pada pasien dengan penyakit kronis tertentu, namun penggunaan pengukuran kualitas hidup sebagai indikator status kesehatan komprehensif pada masyarakat lansia masih sangat terbatas. Mini survei deskriptif potong lintang ini adalah studi percontohan, dilakukan untuk memberikan gambaran preliminari perbandingan hasil penilaian kualitas hidup dengan penilaian kesehatan secara umum, dan keterkaitan antar aspekaspek kehidupan lansia. Sebanyak 28 responden lansia di Jakarta Barat, direkrut dengan metode convenient, mengisi kuesioner kualitas hidup lansia secara daring. Dari 28 responden, 57,1\% menilai tingkat kualitas hidupnya baik (skor 4), rerata skor tertinggi pada aspek spiritual $(81,9)$, sedangkan rerata skor terendah pada aspek kesehatan fisik $(64,7)$. Didapatkan kecenderungan hasil penilaian tingkat kualitas hidup lebih baik (skor lebih tinggi) daripada tingkat kesehatan secara umum. Aspek kesehatan fisik menunjukkan korelasi paling kuat dengan aspek kesehatan mental $(\mathrm{r}=0,84 ; p<0,001)$, dan diikuti dengan aspek lingkungan $(\mathrm{r}=0,75 ; p<0,001)$. Pengukuran kualitas hidup diharapkan dapat memberikan pemahaman komprehensif tentang status kesehatan lansia.
\end{abstract}

Kata Kunci: Lansia, Kualitas Hidup, Status Kesehatan

\begin{abstract}
Indonesia is undergoing a demographic transition towards an older population structure, which not only impacts on the health sector, but also on various aspects of life. The complexity of the aging process and the vulnerability of the elderly to suffer from several chronic diseases, make the concept of "sick vs cured" and indicator of morbidity difficult to reflect the health status and the success of elderly's health programs. Although it is used to evaluate the success of therapy in patients with certain chronic diseases, the use of quality of life as an indicator of comprehensive health status in the elderly community is still very limited. This cross-sectional descriptive mini survey was a pilot study, conducted to provide a preliminary description comparing the results between the quality of life and general health assessments, and the correlation between lives's aspects of the elderly. A total of 28 elderly respondents in West Jakarta conveniently recruited, filled out an online quality of life questionnaire. Of the 28 respondents, $57.1 \%$ rated their quality of life as good (score 4), the spiritual aspect recevied the highest average score (81.9), whilst the physical health aspect received the lowest average score (64.7). There is a tendency for the quality of life level to be better (higher score) than the general health level. Physical health aspects showed the strongest correlation with mental health aspects $(r=0.84 ; p<0.001)$, followed by environmental aspects $(r=0.75$; $p<0.001)$. Measuring the quality of life is expected to provide a comprehensive understanding of the elderly's health status.
\end{abstract}

Keywords: Elderly, Quality Of Life, Health Status

\section{PENDAHULUAN}

\section{Latar Belakang}

Indonesia mengalami transisi demografi dengan populasi penduduk lanjut usia (lansia) meningkat pesat. Menurut data Badan Pusat Statistik (BPS), jumlah lansia di Indonesia hingga tahun 2019 mencapai 25,64 juta orang (sekitar 9.6\% dari total penduduk). Bila persentase penduduk yang berusia di atas 60 tahun mencapai di atas 10\% dari keseluruhan penduduk, maka Indonesia dapat dikategorikan sebagai negara dengan struktur penduduk tua. Struktur penduduk tua tersebut bukan hanya Indonesia secara keseluruhan, tetapi juga tercermin di beberapa 
provinsi di Indonesia, misalnya: Daerah Istimewa Yogyakarta (14,50\%), Jawa Tengah $(13,36 \%)$, Jawa Timur (12,96), Bali (11,30), dan Sulawesi Utara (11,15\%) (Badan Pusat Statistik, 2019).

Tingginya proporsi angka kesakitan dan disabilitas pada kelompok umur ini mengakibatkan kenaikan penduduk lansia berimplikasi pada meningkatnya kebutuhan pelayanan kesehatan primer, sekunder dan tersier, kebutuhan pelayanan home care dan fasilitas perawatan rehabilitatif (Kementerian Kesehatan Republik Indonesia, 2015). Berdasarkan laporan Survei Sosial Ekonomi Nasional (Susenas) pada bulan Maret 2019, angka kesakitan, yang merupakan indikator status kesehatan, mencapai $26,2 \%$ pada lansia Indonesia (yang berarti: satu dari empat lansia Indonesia mengalami sakit), dengan persentase yang semakin meningkat seiring dengan bertambahnya umur lansia (Badan Pusat Statistik, 2019). Hasil Riset Kesehatan Dasar (Riskesdas) 2015 menunjukkan penyakit terbanyak pada lanjut usia adalah hipertensi, artritis, stroke, Penyakit Paru Obstruktif Kronik (PPOK) dan Diabetes Mellitus (DM) (Kementerian Kesehatan Republik Indonesia, 2016). Kondisi tersebut diperburuk dengan kenyataan bahwa lansia sering kali menderita lebih dari satu masalah kesehatan, misalnya: penelitian Abadi et. al. (2013) menemukan bahwa lansia yang menderita penyakit degeneratif seperti hipertensi memiliki risiko lebih besar mengalami gangguan fungsi kognisi (Abadi et al., 2013).

Meningkatnya proporsi penduduk lansia juga berakibat pada meningkatnya rasio ketergantungan, yaitu tanggungan beban ekonomi penduduk usia produktif ( 15 - 59 tahun) untuk membiayai penduduk lansia, termasuk beban perawatan dari penyakit dan diabilitas. Susenas 2019 melaporkan setiap 100 orang penduduk usia produktif 15-59 tahun menanggung 15 orang penduduk lansia. Selain itu, sekitar 8,89\% lansia pernah menjalani rawat inap dalam setahun terakhir, dengan rata-rata lamanya rawat inap sekitar 6 hari (antara $4-7$ hari); ironisnya, satu dari tiga penduduk lansia belum memiliki jaminan kesehatan sehingga menambah beban ekonomi lansia atau pun keluarganya (Badan Pusat Statistik, 2019). Namun sebagaimana di negara sedang berkembang lainnya, lansia Indonesia pun didominasi oleh kelompok lansia potensial yang masih mampu melakukan pekerjaan atau kegiatan yang menghasilkan barang atau jasa. Data Survei Angkatan Kerja Nasional (Sakernas) tahun 2011, sebagaimana dikutip oleh Hermawati, memperlihatkan bahwa 45,41\% lansia masih bekerja. Kondisi ini mempunyai dua arti. Di satu pihak, hal tersebut berarti lansia Indonesia masih produktif, namun sebaliknya juga mengimplikasikan rendahnya tingkat kesejahteraan lansia; bahwa di usia tersebut lansia masih harus dibebani tanggung jawab membiayai dan mencukupi kebutuhan dirinya ataupun keluarganya (Hermawati, 2015). Susenas 2019 juga menunjukkan persentase lansia yang menjadi Kepala Rumah Tangga (KRT) mencapai 61,75\%, terlepas dari apakah lansia produktif atau tidak. Hal tersebut memperlihatkan peran lansia menduduki kelas sosial yang tinggi dalam tatanan sosial masyarakat tradisional Asia, termasuk di Indonesia, sehingga dihormati oleh mereka yang usianya lebih muda (Badan Pusat Statistik, 2019). Namun, juga berarti sebaliknya; sebagaimana umumnya peran KRT, maka tidak menutup kemungkinan bahwa lansia KRT masih membiayai rumah tangganya.

Kondisi yang dihadapi lansia tidak hanya membawa dampak ekonomi namun juga dampak sosial, relasi dengan lingkungan dan psikologis. Penurunan pendapatan karena usia pensiun, kesulitan mendapatkan atau mempertahankan pekerjaan oleh karena keterbatasan fisik, persaingan dengan tenaga kerja yang berusia lebih muda maupun ketidakmampuan mengikuti kecanggihan teknologi, kerap membuat lansia menjadi terpinggirkan dan terisolasi dari masyarakat. Nilai-nilai etika seperti berbakti pada orangtua dan perwujudannya dalam bentuk perawatan dan perhatian terhadap lansia pun terkikis oleh tuntutan karir dan gaya hidup kaum yang lebih muda; akibatnya lansia tinggal sendiri, ataupun hidup bersama keluarganya namun 
kesepian karena sering kali ditinggal sendiri. Keadaan tersebut menyebabkan lansia rentan mengalami gangguan kesehatan baik secara fisik maupun psikologis. Misalnya, menurut Prabhaswari \& Ariastuti (2015), sebesar 24,4\% dari 90 lansia di wilayah kerja Puskesmas Petang I Kabupaten Badung Bali mengalami depresi terutama lansia perempuan dengan tingkat pendidikan rendah, dengan kecenderungan peningkatan angka kejadian depresi seiring dengan bertambahnya usia (Prabhaswari \& Ariastuti, 2015).

Proses penuaan memberi dampak kompleks tidak hanya pada aspek kesehatan namun juga pada berbagai aspek kehidupannya, baik sebagai individu maupun dalam tatanan keluarga dan masyarakat. Apalagi, lansia rentan menderita beberapa penyakit kronis degeneratif yang sulit sembuh, membutuhkan perawatan lama, dan tidak jarang berakhir pada disabilitas di sepanjang usianya. Akibatnya, keberhasilan penanganan masalah kesehatan tidak dapat semata difokuskan pada kondisi "sakit vs sembuh", melainkan diperlukan suatu indikator pengukuran status kesehatan lansia yang bersifat komprehensif, seperti misalnya pengukuran kualitas hidup, yang mencakup aspek kesehatan dan juga aspek-aspek kehidupan lainnya. Demikian pula, penentuan status kesehatan lansia maupun keberhasilan program-program kesehatan lansia, tidak dapat berbasis semata pada indikator angka kesakitan.

Penggunaan pengukuran kualitas hidup mulai sering dimanfaatkan untuk evaluasi pasien yang sedang menjalani pengobatan suatu penyakit tertentu, termasuk di fasilitas-fasilitas pelayanan kesehatan di Indonesia (Hantoro et al., 2018; Salim et al., 2017). Namun dalam lingkup kesehatan masyarakat, pengukuran kualitas hidup belum rutin digunakan sebagai indikator status kesehatan komprehensif pada lansia. Untuk itu studi percontohan (pilot study) ini dilakukan bertujuan memberikan gambaran perbandingan hasil penilaian tingkat kualitas hidup dengan penilaian tingkat kesehatan secara umum, dan keterkaitan antar aspek-aspek kehidupan lansia.

\section{Rumusan Masalah}

Dampak proses penuaan tidak hanya pada kesehatan lansia namun terkait berbagai aspek kehidupan lainnya sehingga membutuhkan suatu alat ukur yang bersifat komprehensif. Masih terbatasnya penggunaan pengukuran kualitas hidup sebagai indikator status kesehatan yang bersifat komprehensif pada masyarakat lansia.

\section{METODE PENELITIAN}

Studi percontohan (pilot study) berupa mini survei deskriptif potong lintang mengenai kualitas hidup lansia meliputi lansia yang tinggal di masyarakat kota Jakarta dengan perekrutan responden menggunakan metode convenient. Mini survei ini menghasilkan data preliminari untuk mendukung perencanaan penelitian selanjutnya yang berbasis hipotesis, diikuti secara sukarela oleh 28 lansia anggota suatu komunitas lansia di wilayah Jakarta Barat. Pengumpulan data dilakukan selama bulan Februari - Maret 2021 melalui pengisian kuesioner kualitas hidup lansia Indonesia secara daring dengan media aplikasi Google form.

\section{Pengukuran kualitas hidup lansia}

Digunakan kuesioner kualitas hidup lansia Indonesia menurut Dewi, et al (2018) yang dikembangkan dari alat ukur kualitas hidup lansia WHOQoL-BREF menurut WHO (1997). Terdapat total 29 pertanyaan terdiri dari 2 pertanyaan penilaian mandiri tingkat kualitas hidup dan tingkat kesehatan secara umum, serta penilaian mandiri aspek/domain kualitas hidup yaitu aspek kesehatan fisik ( 7 pertanyaan), kesehatan mental (6 pertanyaan), aspek sosial (3 pertanyaan), aspek lingkungan (8 pertanyaan) dan aspek spiritual (3 pertanyaan). Masingmasing pertanyaan mendapatkan skor antara 1 sampai dengan 5 , dan total skor tiap aspek 
dikonversi ke skala 0 - 100 (Dewi et al., 2018; World Health Organization, 1997). Aspek kesehatan fisik terdiri dari penilaian terhadap kondisi umum, kesehatan, kemampuan fisik dan energi/tenaga yang dimiliki dalam melakukan aktivitas kehidupan sehari-hari, ketergantungan pada obat-obatan dan alat bantu medis, mobilitas, rasa nyeri dan ketidaknyamanan, tidur dan istirahat, serta kapasitas kerja. Aspek kesehatan mental/psikologis terdiri dari penilaian terhadap citra dan penampilan tubuh, perasaan negative/positif, harga diri, kemampuan berpikir/belajar, daya ingat dan konsentrasi. Aspek sosial terdiri dari penilaian terhadap hubungan pribadi, dukungan sosial dan hubungan dengan pasangan / keluarga terdekat. Aspek lingkungan terdiri dari penilaian terhadap kecukupan sumber keuangan, kebebasan, keamanan fisik dan rasa aman, aksesibilitas dan kualitas layanan kesehatan dan perawatan sosial, lingkungan rumah, peluang untuk memperoleh informasi dan keterampilan baru, partisipasi dan kesempatan untuk rekreasi / kegiatan yang menyenangkan, kondisi lingkungan fisik (polusi / kebisingan / lalu lintas / iklim) (World Health Organization, 1997). Aspek spiritual merupakan aspek unik pada lansia Indoneisa, merupakan cermin kearifan lokal yang umum ditemukan pada tatanan masyarakat lansia di Indonesia, merupakan bagian dari aspek kesehatan mental namun secara khusus memberikan penilaian terhadap pengaruh spiritualitas / agama / keyakinan pribadi dalam kehidupan lansia (Dewi et al., 2018).

\section{Analisa data}

Hasil survei diolah dengan metode deskriptif untuk mendapatkan gambaran mengenai kualitas hidup lansia Indonesia beserta aspek/domainnya, dan kesehatan lansia secara umum. Analisa non-parametrik korelasi Spearman digunakan untuk menentukan adanya hubungan antar aspek/domain kualitas hidup dengan batas kemaknaan $p<0,05$.

\section{HASIL DAN PEMBAHASAN}

Mini survei pada 28 lansia ini diikuti mayoritas perempuan $(96,4 \%)$ dan berusia dalam rentang 60-74 tahun $(78,6 \%)$; terbanyak tamatan pendidikan tinggi $(39,3 \%)$, serta sudah pensiun dan tidak bekerja lagi $(42,9 \%)$. Dari 28 responden lansia tersebut, mayoritas tinggal dengan keluarga terutama dengan anak/cucu $(46,4 \%)$, dan mengikuti $2-3$ komunitas $(42,9 \%)$ (Tabel 1).

Tabel 1. Karakteristik responden $(\mathrm{N}=28)$

\begin{tabular}{lc}
\hline & Jumlah (\%) \\
\hline Jenis Kelamin & $27(96,4)$ \\
\hline Perempuan & $1(3,6)$ \\
\hline Laki-laki & $22(78,6)$ \\
\hline Usia & $6(21,4)$ \\
\hline $60-74$ tahun & $2(7,1)$ \\
\hline$\geq 75$ tahun & $2(7,1)$ \\
\hline Pendidikan terakhir & $8(28,6)$ \\
\hline Tidak sekolah hingga tamat SD & $5(17,9)$ \\
\hline Tamat SLTP / setara & $11(39,3)$ \\
\hline Tamat SLTA / kejuruan / setara & $2(7,1)$ \\
\hline Tamat Akademi & $4(14,3)$ \\
\hline Tamat Pendidikan Tinggi (S1) dan Lanjutan (S2/S3/Profesi) & $12(42,9)$ \\
\hline Status pekerjaan & $5(17,8)$ \\
\hline Sejak awal hingga sekarang masih bekerja (pekerjaan tetap) & $5(17,9)$ \\
\hline Sejak awal hingga sekarang kadang-kadang saja bekerja (sambilan) \\
\hline Sudah pensiun dan tidak bekerja lagi & $10(35,7)$ \\
\hline Bekerja lagi setelah pensiun & \\
\hline Sejak awal tidak bekerja &
\end{tabular}


Anak atau cucu

\begin{tabular}{lc} 
Anak atau cucu & $13(46,4)$ \\
\hline Kerabat (saudara / keponakan / sepupu) & $3(10,7)$ \\
\hline Pekerja (asisten / pengasuh / supir) & $2(7,2)$ \\
\hline Jumlah komunitas aktif diikuti & $8(28,6)$ \\
\hline 1 komunitas & $12(42,9)$ \\
\hline $2-3$ komunitas & $8(28.6)$ \\
\hline$>3$ komunitas
\end{tabular}

Pada 28 responden tersebut, terbanyak adalah lansia yang menilai tingkat kualitas hidupnya baik $(57,1 \%)$, sedangkan untuk tingkat kesehatan secara umum didapatkan proporsi sebanding antara lansia yang merasa puas $(46,4 \%)$ atau pun merasa cukup (46,4\%) (Tabel 2). Gambaran ini sejalan dengan hasil penelitian Puspanegara dan Ronoatmodjo di daerah Kuningan, Jawa Barat pada tahun 2017 yang mendapatkan 53,7\% dari 349 lansia responden lansia menilai kualitas hidupnya baik dengan mayoritas responden adalah perempuan $(57.4 \%)$, berusia $60-74$ tahun $(82,6 \%)$, tidak bekerja $(65,3 \%)$ dan tinggal dengan keluarga $(62,8 \%)$ (Indrayani \& Ronoatmodjo, 2018). Pada penilaian masing-masing aspek/domain kualitas hidup, didapatkan rerata skor tertinggi pada aspek spiritual $(81,9)$ dan rerata skor terendah pada aspek kesehatan fisik $(64,7)$ diikuti rerata skor aspek kesehatan mental $(65,3)$ (Tabel 2). Aspek spiritual mendapatkan skor tertinggi kemungkinan karena responden berasal dari komunitas berbasis spiritual. Aspek kesehatan fisik maupun kesehatan mental mendapatkan skor lebih rendah dari skor aspek sosial, lingkungan maupun spiritual; hal ini sesuai dengan didapatkannya proporsi responden yang merasa tidak puas dengan tingkat kesehatan secara umum (skor 2) dan sebaliknya tidak didapatkan responden yang menilai kualitas hidupnya buruk ataupun sangat buruk (skor $1 \& 2$ ). Demikian pula, didapatkan proporsi responden yang lebih kecil pada mereka yang menilai skor 3,4 , atau pun 5 untuk tingkat kesehatan secara umum daripada proporsi responden yang menilai dengan skor yang sama untuk tingkat kualitas hidup. Dari hasil tersebut menunjukkan, individu lansia dapat memiliki kondisi kesehatan yang kurang baik dan merasa tidak puas dengan keadaan kesehatannya, namun belum tentu menilai kualitas hidupnya buruk. Gambaran tersebut mendukung definsi dan konsep kualitas hidup yang bersifat multi-dimensi, tidak hanya tentang kesehatan seseorang, tetapi lebih luas karena mencakup fungsi dan peran seseorang secara sosial, relasinya terhadap lingkungan dan spiritualitasnya (Post, 2014; Tonon, 2015; Dewi, 2018).

Tabel 2. Gambaran penilaian kualitas hidup dan kesehatan secara umum pada lansia $(\mathrm{N}=28)$

\begin{tabular}{|c|c|c|c|}
\hline Penilaian & Jumlah (\%) & $\begin{array}{c}\text { Rerata } \\
\text { (simpang baku) }\end{array}$ & $\begin{array}{c}\text { Nilai tengah } \\
\text { (minum; maksimum) }\end{array}$ \\
\hline \multicolumn{4}{|l|}{ Tingkat kualitas hidup } \\
\hline Sangat baik (skor 5) & $2(7,1)$ & & \\
\hline Baik (skor 4) & $16(57,1)$ & & \\
\hline Cukup (skor 3) & $10(35,7)$ & & \\
\hline Buruk (skor 2) & 0 & & \\
\hline Sangat buruk (skor 1) & 0 & & \\
\hline \multicolumn{4}{|l|}{ Tingkat kesehatan secara umum } \\
\hline Sangat puas (skor 5) & $1(3,6)$ & & \\
\hline Puas (skor 4) & $13(46,4)$ & & \\
\hline Cukup (skor 3) & $13(46,4)$ & & \\
\hline Tidak puas (skor 2) & $1(3,6)$ & & \\
\hline Sangat tidak puas (skor 1) & 0 & & \\
\hline \multicolumn{4}{|l|}{ Skor masing-masing aspek kualitas hidup } \\
\hline Aspek kesehatan fisik & & $64,7(13,7)$ & $63,5(38 ; 100)$ \\
\hline Aspek kesehatan mental/psikologis & & $65,3(12,9)$ & $66(25 ; 94)$ \\
\hline Aspek sosial & & $69,6(15,0)$ & $72(25 ; 100)$ \\
\hline Aspek lingkungan & & $65,8(11,5)$ & $66(44 ; 88)$ \\
\hline
\end{tabular}


Pada Tabel 3 ditampilkan distribusi penilaian kesehatan secara umum menurut penilaian kualitas hidup. Diantara 28 responden survei, terdapat 1 responden yang merasa tidak puas dengan tingkat kesehatannya (skor 2), namun menilai kualitas hidup-nya cukup (skor 3). Pada 13 dari 28 responden yang merasa cukup puas dengan kesehatannya (skor 3), kira-kira separuhnya (7 orang atau 53,8\%) menilai kualitas hidupnya setara yaitu cukup (skor 3) dan sisanya (6 orang atau 46,2\%) menilai kualitas hidupnya baik (skor 4). Demikian halnya dengan 13 responden yang merasa puas dengan kesehatannya (skor 4), terdapat 2 responden yang menilai kualitas hidupnya cukup (skor 3) dan 1 responden menilai tingkat kualitas hidupnya sangat baik (skor 5). Dari hasil tersebut, tampak adanya pola kecenderungan responden menilai tingkat kualitas hidupnya lebih baik daripada tingkat kesehatan secara umum; yang mana hal ini sesuai dengan konsep kualitas hidup bahwa kualitas hidup seseorang merupakan resultan dari aspek kesehatan dan aspek-aspek kehidupan lainnya (Post, 2014; Theofilou, 2013).

Tabel 3. Distribusi responden menurut tingkat kesehatan secara umum dan tingkat kualitas hidup $(\mathrm{N}=28)$

\begin{tabular}{lcccccc}
\hline \multirow{2}{*}{ Tingkat kesehatan } & \multicolumn{2}{c}{ Jumlah responden menurut tingkat kualitas hidup (N) } \\
\cline { 2 - 5 } & $\begin{array}{c}\text { Sangat buruk } \\
\text { (skor 1) }\end{array}$ & $\begin{array}{c}\text { Buruk } \\
\text { (skor 2) }\end{array}$ & $\begin{array}{c}\text { Cukup } \\
\text { (skor 3) }\end{array}$ & $\begin{array}{c}\text { Baik (skor } \\
4)\end{array}$ & $\begin{array}{c}\text { Sangat baik } \\
\text { (skor 5) }\end{array}$ & $\begin{array}{c}\text { Total } \\
\text { Sangat tidak puas (skor 1) }\end{array}$ \\
\hline Tidak puas (skor 2) & 0 & 0 & 0 & 0 & 0 & 0 \\
\hline Cukup (skor 3) & 0 & 0 & $\mathbf{1}$ & 0 & 0 & 1 \\
\hline Puas (skor 4) & 0 & 0 & $\mathbf{7}$ & $\mathbf{6}$ & 0 & 13 \\
\hline Sangat puas (skor 5) & 0 & 0 & 0 & 0 & $\mathbf{1 0}$ & 13 \\
\hline
\end{tabular}

Hasil korelasi Spearman antar aspek/domain kualitas hidup (Tabel 4) memperlihatkan pada 28 responden tersebut didapatkan adanya hubungan bermakna antar aspek/domain, dengan koefisien korelasi terbesar adalah antara aspek kesehatan fisik dengan kesehatan mental $(\mathrm{r}=0,83$; $p<0,001)$, dan koefisien korelasi terkecil adalah antara aspek sosial dengan spiritual $(\mathrm{r}=0,39$; $p=0,04)$. Aspek kesehatan fisik menunjukkan korelasi paling kuat dengan aspek kesehatan mental ( $\mathrm{r}=0,84 ; p<0,001)$; hal ini mendukung konsep kualitas hidup mengenai keterkaitan antar aspek dan didukung oleh kajian teoritis bahwa pada lansia yang memiliki beberapa penyakit kronik serta komorbiditas lebih rentan untuk mengalami gangguan kesehatan mental, misalnya depresi (Seo et al., 2017). Sebaliknya, masalah kesehatan mental juga dapat meningkatkan risiko berbagai penyakit kronik degeneratif seperti penyakit kardiovaskular, autoimun, masalah neurokognitif (demensia), dll, yang pada akhirnya berdampak pada menurunnya kualitas hidup lansia (Gerst-Emerson \& Jayawardhana, 2015). Korelasi kedua terkuat adalah antara aspek kesehatan fisik dan aspek lingkungan $(\mathrm{r}=0,75 ; p<0,001)$ juga sesuai dengan konsep kualitas hidup mengenai keterkaitan antar aspek. Tingginya angka kejadian kesakitan pada golongan usia lansia (aspek kesehatan fisik) meningkatkan pula kebutuhan dan aksesibilitas terhadap layanan kesehatan, perawatan sosial, kecukupan sumber keuangan, dan peluang untuk memperoleh informasi termasuk informasi kesehatan (aspek lingkungan) (Kementerian Kesehatan Republik Indonesia, 2015). Dalam kaitan antara penilaian kualitas hidup dan penilaian kesehatan secara umum, pada kelompok responden ini, penilaian tingkat kesehatan secara umum yang dilakukan responden kemungkinan mencerminkan kondisi gabungan kesehatan fisik dan kesehatan mentalnya; dan bersama-sama dengan aspek-aspek lainnya (sosial, lingkungan, spiritual) menentukan tingkat kualitas hidupnya. Fenomena hubungan antar aspek/domain kualitas hidup tersebut menarik untuk diteliti lebih lanjut dengan jumlah responden yang lebih banyak dan dengan metode perekrutan yang lebih mewakili populasi lansia 
Indonesia. Gambaran ini juga dapat mendukung indikasi pengukuran kualitas hidup sebagai suatu indikator status kesehatan lansia yang bersifat komprehensif, karena kesehatan lansia dipengaruhi berbagai aspek dan juga dapat berdampak pada berbagai aspek kehidupan lainnya.

Tabel 4. Korelasi antar aspek / domain kualitas hidup ( $\mathrm{N}=28)$

\begin{tabular}{|c|c|c|c|c|c|}
\hline & \multicolumn{5}{|c|}{ Korelasi antar aspek/domain $(\mathrm{r})^{*}$} \\
\hline & Kesehatan fisik & $\begin{array}{c}\text { Kesehatan mental / } \\
\text { psikologis }\end{array}$ & Sosial & Lingkungan & Spiritual \\
\hline Kesehatan fisik & 1 & $0.83^{\dagger}$ & $0.64^{\dagger}$ & $0.75^{\dagger}$ & $0.57^{\dagger}$ \\
\hline Kesehatan mental/psikologis & & 1 & $0.64^{\dagger}$ & $0.68^{\dagger}$ & $0.51^{\dagger}$ \\
\hline Sosial & & & 1 & $0.49^{\dagger}$ & 0.39 \\
\hline Lingkungan & & & & 1 & $0.45^{*}$ \\
\hline Spiritual & & & & & 1 \\
\hline $\begin{array}{l}\text { Keterangan: } \\
* \text { Nilai adalah koefisien korel } \\
\dagger \text { Bermakna secara statistik pa } \\
\text { † Bermakna secara statistik pa }\end{array}$ & rman & & & & \\
\hline
\end{tabular}

\section{KESIMPULAN DAN SARAN}

Peningkatan populasi lansia Indonesia yang signifikan serta kompleksitas proses menua dan dampaknya menjadikan masalah kesehatan lansia perlu dipahami sebagai konsep multi-aspek. Keterkaitan antar aspek merupakan alasan dibutuhkannya pengukuran kualitas kehidupan sebagai suatu indikator yang sanggup menilai kesehatan lansia secara menyeluruh, baik kesehatan fisik maupun psikologis, serta aspek-aspek lain yang terkait erat dengan kesehatan, seperti aspek sosial, lingkungan dan spritual. Pemahaman tentang kesehatan lansia secara menyeluruh tersebut diharapkan dapat bermanfaat untuk memfasilitasi perencanaan, penentuan dan penilaian keberhasilan baik talaksana komprehensif yang efektif maupun program-program kesehatan untuk lansia. Dibutuhkan penelitian-penelitian lebih lanjut untuk membuktikan manfaat penggunaan pengukuran kualitas hidup sebagai indikator status kesehatan komprehensif pada masyarakat lansia.

\section{Ucapan Terima Kasih (Acknowledgement)}

Penulis mengucapkan terima kasih kepada lansia anggota komunitas yang secara secara sukarela telah berpartisipasi dalam mini survei ini, dan kepada ibu E.H dan ibu E.S sebagai pengurus komunitas lansia yang telah membantu menghubungkan penulis dengan lansia anggota komunitas serta mendistribusikan tautan survei.

\section{REFERENSI}

Abadi, K., Wijayanti, D., Gunawan, E. A., Rumawas, M. E., \& Sutrisna, B. (2013). Hipertensi dan risiko mild cognitive impairment pada pasien usia lanjut. Jurnal Kesehatan Masyarakat Nasional 8(3), 119-124.

Badan Pusat Statistik. (2019). Statistik penduduk lanjut usia (04220.1905). https://www.bps.go.id/publication/download.

Dewi, F. I. R., Rostiana, \& Rumawas, M. E. (2018). The assessment model of quality of life in Indonesian elderly [Confrence Proceedings]. Advanced Science Letters, 24, 417-419.

Gerst-Emerson, K., \& Jayawardhana, J. (2015). Loneliness as a public health issue: the impact of loneliness on health care utilization among older adults. Am J Public Health, 105(5), 10131019.

Hantoro, I. F., Syam, A. F., Mudjaddid, E., Setiati, S., \& Abdullah, M. (2018). Factors associated with health-related quality of life in patients with functional dyspepsia. Health Qual Life Outcomes, 16(1), 83. 
Hermawati, I. (2015). Kajian tentang kota ramah lanjut usia. Disampaikan pada Seminar dan Lokakarya Tentang Kota Ramah Lansia, Yogyakarta, 23 April 2015.

Indrayani, \& Ronoatmodjo, S. (2018). Faktor-faktor yang berhubungan dengan kualitas hidup lansia di desa Cipasung Kabupaten Kuningan tahun 2017. Jurnal Kesehatan Reproduksi, 9(1), 69-78.

Kementerian Kesehatan Republik Indonesia. (2015). Rencana strategis Kementerian Kesehatan RI tahun 2015-2019. https://www.kemkes.go.id/resources/download/info-publik/Renstra2015.pdf

Kementerian Kesehatan Republik Indonesia. (2016). Situasi lanjut usia (lansia) Indonesia [Monograf]. https://www.kemkes.go.id/resources/download/pusdatin/infodatin/.

Post, M. W. (2014). Definitions of quality of life: what has happened and how to move on. Top Spinal Cord Inj Rehabil, 20(3), 167-180.

Prabhaswari, L., \& Ariastuti, N. L. P. (2015). Gambaran kejadian depresi pada lanjut usia di wilayah kerja Puskesmas Petang I Kabupaten Badung Bali 2015. Isainsmedis, 7(1), 47-52.

Salim, S., Yamin, M., Alwi, I., \& Setiati, S. (2017). Validity and Reliability of the Indonesian Version of SF-36 Quality of Life Questionnaire on Patients with Permanent Pacemakers. Acta Med Indones, 49(1), 10-16.

Seo, J., Choi, B., Kim, S., Lee, H., \& Oh, D. (2017). The relationship between multiple chronic diseases and depressive symptoms among middle-aged and elderly populations: results of a 2009 korean community health survey of 156,747 participants. BMC Public Health, 17(1), 844.

Theofilou, P. (2013). Quality of Life: Definition and Measurement [Theoritical contributions]. Europe's Journal of Psychology, 9(1), 150-162.

Tonon, G. (2015). Relevance of the use of qualitative methods in the stydy of quality of life. In G. Tonon (Ed.), Qualitative Studies in Quality of Life: methodology \& practice (1 ed., pp. 3-21). Springer International Publishing.

World Health Organization. (1997). WHOOOL Measuring Quality of Life https://www.who.int/mental_health/media/68.pdf 